\author{
International Journal of Education, \\ Psychology and Counselling (IJEPC) \\ Journal Website: http://ijepc.com/ \\ eISSN: 0128-164X
}

\title{
INVESTIGATING THE RELATIONSHIP BETWEEN TEACHER ATTITUDE, READINESS, INTEGRITY, AND SCHOOL-BASED ASSESSMENT
}

\author{
Mohd Malik Tu${ }^{1}$, Mohamad Nizam Nazarudin ${ }^{2 *}, Z_{\text {Zakiah Noordin }}^{3}$, Ajilin Tawan ${ }^{4}$, Norlijah Watinin ${ }^{5}$
}

1 Rural Education Unit, Faculty of Psychology and Education, Universiti Malaysia Sabah, Kota Kinabalu, Sabah

2 Rural Education Unit, Faculty of Psychology and Education, Universiti Malaysia Sabah, Kota Kinabalu, Sabah

Email: mnizam@ums.edu.my

$3 \quad$ Institut Pendidikan Guru Kampus Gaya, Sabah

Email: zakiahnoordin@gmail.com

4 Rural Education Unit, Faculty of Psychology and Education, Universiti Malaysia Sabah, Kota Kinabalu, Sabah

5 Rural Education Unit, Faculty of Psychology and Education, Universiti Malaysia Sabah, Kota Kinabalu, Sabah

* Corresponding Author

\section{Article Info:}

\section{Article history:}

Received date: 19.12 .2018

Revised date: 31.12 .2018

Accepted date: 14.06 .2020

Published date: 15.06 .2020

\section{To cite this document:}

Tu, M. M., Nazarudin, M. N., Noordin, Z., Tawan, A., \& Watinin, N. (2020). Investigating the Relationship Between Teacher Attitude, Readiness, Integrity and School Based Assessment. International Journal of Education, Psychology and Counseling, 5 (35), 306-320.

DOI: $10.35631 /$ IJEPC.5350026.

\begin{abstract}
:
The assessment of education in Malaysia aims to obtain information on student performance to fully develop the potential of individuals as harmonious and balanced human capital in line with the National Philosophy of Education. The purpose of this study is to identify the relationship between teacher attitude, readiness, integrity, and the implementation of School-Based Assessment (SBA) based on the Primary School Curriculum (PSC). A total of 297 primary school teachers in the Ranau district were selected as respondents in this study to answer the questionnaire. Data were processed and analyzed using Statistic Package for Social Science (SPSS) Version 26.0. The findings show that the level of teacher attitude is intermediate but that teachers' readiness and integrity towards the implementation of school-based assessments are high. There is a positive and high relationship between teacher attitude, readiness, integrity, and School-Based Assessment. In addition to teachers needing to be positive, ready, and honest, teachers will find that SBA has many benefits and can reduce the burden of teacher work if handled and implemented wisely.
\end{abstract}

\section{Keywords:}

Attitude, Readiness, Integrity, School-Based Assessment, Teacher, Primary School 


\section{Introduction}

The new assessment available in Malaysia is designed by the Malaysian Examination Board (MEB) and is planned, administered, discounted and reported by the school. According to Ali (2008), assessment in the teaching and learning process is an important aspect that can help to enhance the effectiveness of the teaching and learning process while also unlocking the potential and talent of students. School-Based Assessments (SBA) can be defined as a form of holistic assessment that assesses the cognitive (intellectual), affective (emotional and spiritual) and psycho-motor (physical) aspects in accordance with the National Education Philosophy and Primary School Curriculum (PSC). In addition, SBA also contains other important elements such as goals and distribution of components in the implementation of SBA. As such, teachers are given the responsibility to act as individuals who will facilitate the SBA implementation process throughout the school. The question that arises is to which extent teachers' attitudes, readiness and integrity are implemented in SBA. This study will look at some aspects of the attitude, readiness and integrity of teachers in the Ranau district when conducting School-Based Assessment at the school.

In the Malaysian education system for over 50 years, examinations are the main method used to measure student achievement. Therefore, school-based assessment is introduced to improve the assessment system for student-based exams. When this school-based assessment system was introduced, teachers were the most important individuals in the success of the government's change. This is because the assessment component must be conducted by the school and its assessment is carried out by the subject teachers continuously in the teaching and learning process. The assessments are planned, discounted and reported in accordance with the procedures prescribed by the Malaysian Examination Board. School based assessment is part of the candidate's assessment in the course including syllabus. It is intended to assess specific knowledge, skills and attitudes related to the subject and is not easily assessed in external examinations. Activities under SBA are associated with syllabus and should be part of the learning activities to enable candidates to achieve the syllabus objectives. Throughout the course of all subjects, students will be rated by the teacher for specific knowledge, skills and attitudes of students performing SBA School assignments. These marks contribute to the final grades and grades given to students for achievement in the examination.

\section{Problem Statement}

As a result of this implementation of SBA, teachers are empowered to develop their teaching creativity (Maxwell, 2006). Teachers deliver a variety of teaching and assessment based on the ability of the students in their class. The advantage of SBA is that to generate creative teaching and learning activities, teachers must use a variety of assessment methods to evaluate learning outcomes (Azlin Norhaini et al., 2013). Teachers also need to use different teaching methods to ensure effective learning. Through this SBA, teachers are also able to apply Higher-order thinking skills (HOTS) while teaching. Indirectly the learning environment is more studentcentered. The relationship between students and teachers will also be closer as they will have the curiosity and the courage to speak up in resolving non-routine issues raised by their teachers or peers. In addition, teachers can indirectly convey the hidden curriculum of building values towards balanced human formation. Applying this kind of teaching is important to help students feel comfortable accepting new forms of millennial learning. At the same time helping them to face general exams that are more formidable. The implementation of the SBA also provided a new way of working for school executives. More integrated work is the teamwork culture that is implemented in schools. The administrators and teachers discuss and develop effective implementation strategies to ensure that SBA in schools is effective. 
Training for students is provided in more structured and evidenced by teachers before teaching and learning sessions. This kind of work environment when viewed in a positive way will create a fun work culture in the school. To facilitate the effective implementation of SBA, the ministry has also set up two ICT systems, SPSBA and PAJSK. In the previous examinationbased assessment system, the implementation of the learning and teaching process for Physical Education and Art Education subjects for Form 3 students was conducted for one term only. But after the introduction of SBA, this subject also played an important role in realizing the National Philosophy of Education. Therefore, all teachers need to take their role seriously. This is supported by the features of SBA's concept of PADI (Profile, Achievement, Development, and Involvement). Students are not only judged on the acronym aspect but include all components. Furthermore, teachers can see the development of students in general. This can be assessed more clearly with the help of the SPSBA system. Hopefully this system can be improved because the information in the system if it operates smoothly will greatly benefit teachers.

In 2011, the national education system witnesses the implementation of SBA for standard 1 and Form 1 class. The implementation of SBA was too early to assess. The Malaysian Education Development Plan (2013-2025) explains that the biggest challenge faced by the Ministry of Education (MOE) in this decade is to reduce school-based learning in the form of examinations but not doing so is not an easy task. Thus, in achieving the goals and objectives of the SBA implementation, teacher attitude, readiness and integrity play a key role. Changes from the old curriculum to the new have had an impact on teacher teaching and learning in schools. This is because the PSC emphasizes the implementation of the SBA method to make teaching and learning more enjoyable and not too exam oriented. This situation requires teachers to be well prepared for each teaching session as PSC enables the assessment to be holistic and the teacher needs to see the progress and achievement of the students individually.

In addition, the liquidity of the information is unclear and consistent as it is conveyed through courses at the school level without being monitored by their respective State Education Department (SED) officials (Ismadiah, 2012). This is evident when the SBA system in schools is different from one another. Teachers assigned to teach according to the new curriculum syllabus also feel burdened with a syllabus that emphasizes student achievement as a whole and needs to meet established standards. This situation causes teachers to give negative perceptions to the assessment system to see student progress and achievement. Therefore, the implementation of school-based assessment is seen as a new challenge for teachers in terms of the integrity and readiness of these groups as implementer (Maslin, 2014). As SBA is run by teachers in schools, the quality aspect is very important.

There is still a problem in controlling the quality of observations based on observation and evaluation (Stiggins \& Bridgeford, 1985). The provision of excessive assessment instruments can increase the existing burden of teachers and there is also a shortage of infrastructure in the interior which could adversely affect the effectiveness of implementation of assessments such as the shortage of printers, files and computers. This problem of integrity can also be due to teachers burdened with administrative and co-curricular tasks. This has led to the integrity of implementing SBA as a single product rather than a compulsory and ongoing process coupled with time constraints that make it less creative.

\section{Literature Review}

The assessment of education in Malaysia aims to gain information on student performance to fully develop the potential of each individual as a harmonious and balanced human capital in 
line with the National Philosophy of Education. The process of improvement introduced by the Education Ministry through SBA provides the impression that centralized examination systems like UPSR and PMR are no longer the only form of assessment in measuring student achievement in learning. Moreover, it is hoped that it will produce students who excel in all aspects as their assessment is done from an early stage and is not only limited to academics but also includes personality, sports and co-curriculum. Students are judged fairly as individuals in society based on their abilities, abilities, talents, skills and potentials without being compared to others. The school is able to provide complete feedback in the form of qualitative and quantitative data that covers all aspects of a student's identity so that those responsible can recognize, understand, appreciate, recognize and glorify learners as useful, important and potential human beings.

The Primary School Curriculum (KSSR) curriculum changes the content and teaching practices. It is seen that KSSR emphasizes 4M mastery including judgmental skills and others such as the basics of ICT development of socio-emotional, spiritual, physical, attitude and values compared to 3M in KBSR (New Elementary Curriculum). The year 2011 marked a turning point in the education system in Malaysia when the SBA was introduced to Year 1 primary school students. The change is the difference between the current and previous situation (Amir Hassan, 2006) in which the assessment of the students has been changed to the School Based Assessment to replace the exam-oriented assessment. Implementation of various changes in the education system has certainly made the role and responsibilities of teachers more challenging (Amir Hassan, 2006). The study conducted by Zurida and Nooraisa (n.d) was to identify the issues that arise during the implementation of the KSSR in 2011 in terms of compliance. Data is collected through structured interviews and the study sample consisted of 8 teachers from 4 schools who taught Year One subjects. The teachers interviewed are still unclear about the concept of abduction because they are unable to properly define and interpret it. All teachers are unsure of the methods and approaches they should use during the teaching and learning process in an effort to apply and enhance their students' teaching skills. Examoriented assessments have been replaced with School-Based Assessments developed by the Ministry of Education, making the tasks and responsibilities of teachers more challenging

Sanitah and Norsiwati (2012) in their study have identified that the level of teacher readiness in terms of interest, attitude and mastery of knowledge and skills in implementing KSSR has used questionnaire as a research instrument. The study sample consisted of 50 first year math teachers in Klang District. The findings show that the longer a teacher teaches in the 1st year, the greater the motivation to convey knowledge. This clearly indicates that the willingness, interest and positive attitude of teachers who teach Year 1 math will have a positive impact on the implementation of the KSSR. Most teachers say this KSSR is good but a clearer and more detailed explanation is given to all teachers in terms of teaching and assessment strategies in achieving $3 \mathrm{M}$ skills such as writing, reading, counting and rating. For the $3 \mathrm{M}$ skills of reading, writing and counting, no problem arises but for the proficiency of teachers find that teachers are not sure how to apply and determine how well students have mastered those skills. Most teachers expect exposures and courses that focus on good teaching skills to be given to teachers (Nazarudin et al, 2017).

\section{Research Objective}

The purpose of this study was to examine the relationship between teacher attitude, readiness integrity and school-based assessment (SBA) in Ranau district while the objectives of this study were to: 
1. Identify the level of attitude, readiness, integrity and school-based assessment among primary school teachers in Ranau district.

2. Identify the difference in attitude, readiness, integrity and school-based assessment based on gender, age and teaching experience among primary school teachers in Ranau district.

3. Identify the relationship between attitude, readiness, integrity and school-based assessment among primary school teachers in Ranau district.

\section{Study Framework}

Figure 1 is a framework designed to show the process through which teachers' attitudes, readiness, integrity and school-based assessment among primary school teachers in the Ranau district.

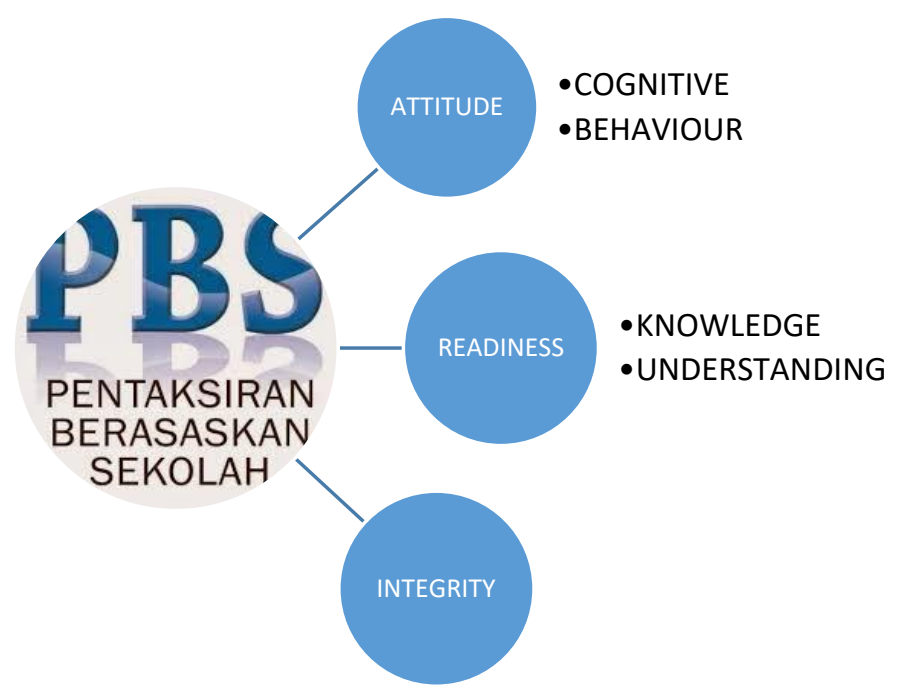

Figure 1: Research Conceptual Framework

\section{Research Design}

The design of this study is quantitatively non-experimental, which is in the form of descriptive and correlation studies. Descriptive studies will be conducted to identify respondent's demographic information while correlation studies will be used to measure the strength of the relationship between independent variables (teacher attitude, readiness and integrity) and dependent variables (school-based assessment) based on teachers' perceptions. According to Gay and Airasian (2003), correlation studies determine the degree of strength of the relationship that exists between two or more variables. However, this correlation study cannot explain the relationship between the reason for the variables and the absence of manipulation of variables in the study (Fraenkel \& Wallen, 2006). The population of teachers is 1308 in seventy-one primary schools located in Ranau District, Sabah. The sample size of the respondents is based on Krejcie and Morgan's (1970) table of 297 people. Group sampling techniques and proposition techniques to determine the sample size by zone (Syafinaz, 2017). To reduce the sample size of the study, the researcher used a simple random sampling technique. The instrument used in this study was adapted from previous research conducted by Kalawathi (2013), Mohd Safarin and Nur Hidayah (2014), Zalinah (2014), Ramlah et al, (2015) and, Mohd Noor and Sahip (2010). Reliability depends on the level of alpha value which is if the alpha value is above 0.60 it is considered high and acceptable. Both instruments have also undergone a review of the validity of the content and validity of ideas for the validity of the instrument. The purpose of validating a survey is to make sure that a measure is able to measure Copyright (C) GLOBAL ACADEMIC EXCELLENCE (M) SDN BHD - All rights reserved 
what to measure (Ahmad Mahdzan, 2005; Mohd Majid, 2000; Wiseman, 1999). A pilot study was also conducted on 30 primary school teachers who were not involved in the actual study in Ranau district. In the pilot study, the internal consistency test method was performed and obtained alpha values of 0.65 to 0.95 .

Table 1: Reliability of the Questionnaire during Pilot and Real Studies

\begin{tabular}{lccc}
\hline \multicolumn{1}{c}{ QUESTIONNAIRES } & $\begin{array}{c}\text { Question } \\
\text { Number }\end{array}$ & $\begin{array}{c}\text { Pilot Study } \\
\text { Reliability }\end{array}$ & $\begin{array}{c}\text { Real Study } \\
\text { Reliability }\end{array}$ \\
\hline Attitude & 20 & .889 & .894 \\
Readiness & 29 & .972 & .908 \\
Integrity & 12 & .906 & .841 \\
Implementation of School- & 10 & .790 & .846 \\
Based Assessment & & & \\
\hline
\end{tabular}

Data were analysed using parametric test method. All data collected were analysed using Statistical Package For Social Sciences (SPSS) Version 26. Software in the Pearson Correlation Statistical Analysis, t-test and one-way Variance Analysis (ANOVA) were used.

\section{Findings}

\section{Respondents' Demographic Profiles Consist of Gender, Age, and Teaching Experience}

Table 2 shows that out of 297 samples, it was found that 142 people or $47.8 \%$ were male teachers while 154 people or $51.9 \%$ were female teachers. The highest age category was between 26 and 30 years of 134 or $45.1 \%$. The lowest age category was between 21 and 25 years old by 25 or $8.4 \%$. While the age group of 31 to 35 is 108 people or $36.4 \%$ and the age group is 36 or $30 \%$ or $10.1 \%$. The highest teaching experience was 10 to 15 years with 92 or $32 \%$, while the lowest teaching experience was 3 and below with 21 or $7.1 \% 16$ to 20 years teaching experience was 74 or $34.9 \%$. Subsequently, teachers with 21 years of experience and above were 57 or $19.2 \%$, and 4- and 9-year-old experienced teachers were 53 or $17.8 \%$.

Table 2: Respondent Distribution By Gender

\begin{tabular}{lcccc}
\hline & Frequency & Percent & $\begin{array}{c}\text { Valid } \\
\text { Percent }\end{array}$ & $\begin{array}{c}\text { Cumulative } \\
\text { Percent }\end{array}$ \\
\hline Gender & & & & \\
Male & 142 & 47.8 & 47.8 & 47.8 \\
Female & 155 & 52.2 & 52.2 & 100.0 \\
Total & 297 & 100.0 & 100.0 & \\
Age & & & & \\
21 - 25 years & 25 & 8.4 & 8.4 & 8.4 \\
$\begin{array}{l}\text { 26-30 years } \\
\text { 31 - 35 years }\end{array}$ & 134 & 45.1 & 45.1 & 53.5 \\
$\begin{array}{l}\text { Above 36 } \\
\text { years }\end{array}$ & 30 & 36.4 & 36.4 & 89.9 \\
Total & 297 & 10.1 & 10.1 & 100.0 \\
Teaching & & 100.0 & 100.0 & \\
Experience & & & & \\
\hline
\end{tabular}




\begin{tabular}{lcccc}
\hline $\begin{array}{l}\text { Below } \\
\text { years }\end{array}$ & 21 & 7.1 & 7.1 & 7.1 \\
4-9 years & 53 & 17.8 & 17.8 & 24.9 \\
10 -15 years & 92 & 31.0 & 31.0 & 55.9 \\
16 -20 years & 74 & 24.9 & 24.9 & 80.8 \\
$\begin{array}{l}\text { Above 21 } \\
\text { years }\end{array}$ & 57 & 19.2 & 19.2 & 100.0 \\
Total & 297 & 100.0 & 100.0 & \\
\hline
\end{tabular}

Level of Teacher Attitude with The Implementation of School-Based Assessment (SBA) in School

Table 3 shows that overall, the attitude of secondary school teachers in Ranau District was moderate $(\mathrm{M}=3.96, \mathrm{SP}=0.07)$ while teacher readiness level $(\mathrm{M}=4.01, \mathrm{SP}=0.87)$, teacher integrity level $(\mathrm{M}=4.07), \mathrm{SP}=0.61)$ and high-level implementation of school-based assessments $(\mathrm{M}=4.06, \mathrm{SP}=0.69)$.

Table 3: Standard Mean And Standard Deviation In Teacher Attitude, Readiness And Integrity Of Schools And School-Based Assessment (SBA) Among Teachers In Ranau

District

\begin{tabular}{lcccc}
\hline & N & Mean & Std. Deviation & Level \\
\hline Attitude & 297 & 3.96 & 0.777 & Intermediate \\
Readiness & 297 & 4.014 & 0.876 & High \\
Integrity & 297 & 4.078 & 0.623 & High \\
$\begin{array}{l}\text { Implementation } \\
\text { of SBA }\end{array}$ & 297 & 4.060 & 0.693 & High \\
\hline
\end{tabular}

\section{Differences In Teachers' Attitudes Based on Gender}

According to Table 4, this means that there were no significant differences in mean $(\mathrm{t}=0.636$, $\mathrm{p}>0.05)$, readiness $(\mathrm{t}=0.747, \mathrm{p}>0.05)$ and integrity $(\mathrm{t}=2.02, \mathrm{p}>0.05)$ between male and female teachers.

Table 4: Test Results For Teachers' Attitudes, Readiness And Integrity And SchoolBased Assessment (SBA) Based On Gender

\begin{tabular}{lcccccc}
\hline & Gender & N & Mean & $\begin{array}{c}\text { Std. } \\
\text { Deviation }\end{array}$ & t & sig. \\
\hline Attitude & Male & 142 & 3.903 & .270 & 0.636 & 0.068 \\
& Female & 155 & 3.934 & .259 & & \\
Readiness & Male & 142 & 4.112 & .205 & 0.747 & 0.402 \\
& Female & 155 & 4.103 & .279 & & \\
Integrity & Male & 142 & 4.083 & .213 & 2.020 & 0.194 \\
& Female & 155 & 4.097 & .297. & & \\
\hline
\end{tabular}

Significant Differences In Teacher Attitudes, Readiness And Integrity And School-Based Assessment (SBA) Are Based On Age

One-way ANOVA results in Table 5 showed no significant differences in teacher attitude [F $(3,296)=0.377, \mathrm{P}>0.05]$, teacher readiness $[\mathrm{F}(3,296)=0.476, \mathrm{P}>0.05]$ and teacher integrity $[\mathrm{F}(3,296)=2.047, \mathrm{P}>0.05]$ by age . 
Table 5: One-Way ANOVA On Teacher Attitude, School Readiness And School-Based Assessment (SBA) Based On Age

\begin{tabular}{|c|c|c|c|c|c|}
\hline & $\begin{array}{c}\text { Sum of } \\
\text { Squares }\end{array}$ & Df & $\begin{array}{c}\text { Mean } \\
\text { Square }\end{array}$ & $\mathbf{F}$ & Sig. \\
\hline Attitude & & & & & \\
\hline $\begin{array}{l}\text { Between } \\
\text { Groups }\end{array}$ & 876.138 & 3 & 292.046 & 3.771 & 0.061 \\
\hline $\begin{array}{l}\text { Within } \\
\text { Groups }\end{array}$ & 22694.112 & 293 & 77.454 & & \\
\hline $\begin{array}{l}\text { Total } \\
\text { Readiness }\end{array}$ & 23570.249 & 296 & & & \\
\hline $\begin{array}{l}\text { Between } \\
\text { Groups }\end{array}$ & 245.635 & 3 & 81.878 & 0.476 & 0.699 \\
\hline $\begin{array}{l}\text { Within } \\
\text { Groups }\end{array}$ & 50384.069 & 293 & 171.959 & & \\
\hline $\begin{array}{l}\text { Total } \\
\text { Integrity }\end{array}$ & 50629.704 & 296 & & & \\
\hline $\begin{array}{l}\text { Between } \\
\text { Groups }\end{array}$ & 151.467 & 4 & 37.867 & 2.047 & 0.088 \\
\hline $\begin{array}{l}\text { Within } \\
\text { Groups }\end{array}$ & 5402.317 & 292 & 18.501 & & \\
\hline Total & 5553.785 & 296 & & & \\
\hline
\end{tabular}

Significant Differences In Teacher Attitude, Readiness And Integrity And School-Based Assessment (SBA) Based On Teaching Experience

One-way ANOVA results in Table 6, showed no significant differences in teacher attitude [F $(4,296)=2.920, \mathrm{P}>0.05]$, teacher readiness $[\mathrm{F}(4,296)=0.681, \mathrm{P}>0.05]$ and teacher integrity $[\mathrm{F}(4,296)=1.840, \mathrm{P}>0.05]$ based on teaching experience.

Table 6: One-Way ANOVA For Teacher Attitude, Readiness And Integrity And SchoolBased Assessment (SBA) Based On Teaching Experience

\begin{tabular}{lccccc}
\hline & $\begin{array}{c}\text { Sum of } \\
\text { Squares }\end{array}$ & Df & $\begin{array}{c}\text { Mean } \\
\text { Square }\end{array}$ & F & Sig. \\
\hline $\begin{array}{l}\text { Attitude } \\
\text { Between }\end{array}$ & 906.652 & 4 & 226.663 & 2.920 & 0.122 \\
$\begin{array}{l}\text { Groups } \\
\text { Within }\end{array}$ & 22663.597 & 292 & 77.615 & & \\
$\begin{array}{l}\text { Groups } \\
\text { Total }\end{array}$ & 23570.249 & 296 & & & \\
$\begin{array}{l}\text { Readiness } \\
\text { Between }\end{array}$ & 468.082 & 4 & 117.021 & 0.681 & 0.605 \\
$\begin{array}{l}\text { Groups } \\
\begin{array}{l}\text { Within } \\
\text { Groups }\end{array}\end{array}$ & 50161.622 & 292 & 171.786 & & \\
$\begin{array}{l}\text { Total } \\
\text { Integrity }\end{array}$ & 50629.704 & 296 & & & \\
$\begin{array}{l}\text { Between } \\
\text { Groups }\end{array}$ & 102.688 & 3 & 34.229 & 1.840 & 0.140 \\
\hline
\end{tabular}




\begin{tabular}{llll}
\hline Within & 5451.096 & 293 & 18.604 \\
Groups & & & \\
Total & 5553.785 & 296 & \\
\hline
\end{tabular}

Relationship of Teacher Attitude, Readiness and Integrity with School-Based Assessment Based on Table 7, it was found that there was a significant positive $(\mathrm{p}<0.05)$ relationship between teacher attitude and implementation of school-based assessments of $r=0.787$ and $p=$ 0.000 . The results also showed that there was a significant $(\mathrm{p}<0.05)$ relationship between teacher readiness and school-based assessments of $r=0.748$ and $p=0.000$. Finally the results showed that there was a significant $(\mathrm{p}<0.05)$ relationship between teacher integrity and the implementation of school-based assessments of $r=0.812$ and $p=0.000$.

Table 7: Teacher Coordination, Readiness and Integrity with School-Based Assessment

\begin{tabular}{lccccc}
\hline School-Based & Pearson & 1 & $.787^{* *}$ & $.748^{* *}$ & $.812^{* *}$ \\
$\begin{array}{l}\text { Assessment } \\
\text { Implementation }\end{array}$ & $\begin{array}{c}\text { correlation } \\
\text { Sig. (2- }\end{array}$ & & .000 & .000 & .000 \\
& $\begin{array}{c}\text { tailed) } \\
\mathrm{N}\end{array}$ & 297 & 297 & 297 & 297 \\
\hline
\end{tabular}

**. Correlation is significant at the 0.01 level (2-tailed).

\section{Discussion}

The Level of Attitude, Readiness and Integrity of Teachers in The Implementation of SchoolBased Assessment

The level of attitude of the teachers in the Ranau district during the implementation of SBA was moderate. In the seventh year of the SBA implementation, teachers have begun to develop a positive attitude towards SBA that is practiced daily in the school. This modest teacher attitude is due to the attitude of teachers who are in the process of understanding their routine tasks in assessing students in the classroom. Pupils are assessed correctly with a variety of assessment techniques that interest and interest students in their learning. This level of teacher attitude depends on the assessment of an object, whether weak or strong which leads to positive, moderate and negative attitudes (Abdul Aziz, 2007). Overall the level of teacher readiness during SBA is high. This is due to high knowledge and understanding factors among the academic teachers in Ranau district. The majority of teachers in the Ranau area are willing to apply for SBA in schools and have attended preservice courses held at district and school levels. This finding is in line with the study of Mohd Isha (2011) who found that teachers gain knowledge and skills after attending internal courses held from time to time in schools. Referring to aspects of the theory of constructivism, one's knowledge is derived from the way human beings build their knowledge within their respective cognitive schemes. Based on the theory of constructivism above, the level of readiness of the teachers in Ranau district is driven by the curiosity and education of the people to success.

The findings show that the level of teacher integrity is high in Ranau district. This high level of teacher integrity is in line with the findings of Noor Suadah (2014) which found high levels of integrity among teachers in four schools in Kulaijaya in the implementation of school-based assessment (SBA). This finding was also supported by Mohd Johdi (2008), who stated that the role of teachers is very important in strengthening the formal education discourse beginning at 
the elementary school level. Therefore, the assessment of students in SBA should be transparent and integrated. Sh. Siti Hauzimah (2019) shows the level of integrity of the national primary school teachers as the implementation of student assessment based on KSSR is at a high level.

The findings also show that the level of implementation of SBA teachers in Ranau district is high. Teachers know and understand clearly the procedure and components of SBA implementation. The findings also show that teachers are good at understanding and understanding school-based assessments as a whole and the content of learning development guides. This situation is due to exposure from school administrators to the relevant teachers. In addition, there is also an increase in information obtained during the district and school level. This finding shows that if teachers have high levels of attitude, readiness and self-esteem then teachers are very prepared and able to understand the purpose and concept of SBA based on the SBA guidelines and regulations as outlined by the Malaysian Examination Board (2011).

\section{Differences in Teacher Attitudes, Readiness and Integrity Based on Gender, Age and Teaching Experience}

Primary school teachers in the Ranau area clearly have no difference in attitude, readiness and integrity based on gender, age and teaching experience. The findings of this study are in line with the study of Abdul Said and Shanti (2017) who found no significant difference in the level of teacher integrity based on gender, age and teaching experience. All teachers have a high level of readiness and integrity in the aspect of the SBA assessment skills set by the Malaysian Examination Board regardless of background. This indicates that prior to conducting the assessment the teachers had identified the construct or skills of the assessment in accordance with the objectives, purpose of the assessment and the ability of the student to be assessed. This element is in keeping with Tyler's Model (1949) in Mohd Najib's (2001) which focuses on the objective achievement of an assessment. Goals and objectives that are relevant to the skills being interpreted will be able to bring about change and achievement of behavior and thus enhance students' skills in learning. In addition, this Tyler Model is also very useful in conducting assessments as it is based on objective determination and its assessment is based on the achievement and effectiveness of the objectives set in its early stages (Mohd Najib, 2001). The findings of Mr Azlyna's (2013) study also found that there were no significant differences in teacher attitude levels based on gender, age and teaching experience. The findings of this study are in line with the findings of Aniza and Zamri (2015) who found no significant difference in teacher readiness based on gender, age and teaching experience. Properly managed and implemented, teachers will find that SBA provides many benefits and can reduce teacher workloads regardless of gender, age and teaching experience.

Atan Long (1984) argues that a teacher needs to have a positive attitude such as dedication, self-reliance, responsibility, dedication, boldness and courage in the face of challenges. In implementing this school-based assessment, teachers need to have a positive attitude such as always preparing well before teaching to ensure that teaching and assessment can be carried out smoothly. Sanitah and Norsiwati (2012) find that the longer a teacher teaches year 1, the more likely they are to develop a passion for delivering knowledge. This clearly indicates that the willingness, interest and positive attitude of Year 1 math teachers will have a positive impact on the implementation of the KSSR regardless of demographic background. To help teachers implement SBA, two ICT applications have been developed to ensure that teachers are not burdened with clerical tasks. SPSBA (School-Based Assessment Management System) and PAJSK (Physical Activity, Sports and Curriculum Assessment) were developed to record, store and report student progress. Stored data can be printed as reports when needed. 


\section{The Relationship Of Teacher Attitude, Readiness And Integrity With The Implementation Of School-Based Assessment}

The results show that there is a positive correlation between high levels of teacher attitude, readiness and integrity with the implementation of school-based assessments. This shows that the higher the attitude of the Ranau district teachers, the higher the implementation of schoolbased assessments in the Ranau district. Referring to the teacher's attitude towards schoolbased assessment, the teacher's attitude would be positive if the teacher felt that the transformation of the assessment introduced benefits in enhancing the country's education system and producing holistic values and benefiting future human capital. School-Based Assessment (SBA) was introduced by the Ministry of Education Malaysia in primary schools throughout Malaysia in 2011 and secondary schools during the 2012 school session. However, its implementation has raised many issues in society since its introduction and is no exception among teachers.

The findings of this study are in line with the findings of Chew and Muhamad (2017) who found that teachers' readiness in the aspects of skills is significantly influenced by the implementation of School Based Assessment. The credibility of a teacher will be disputed when the teacher lacks preparation for teaching and learning. As a result, students are less aware of the content of the lessons presented. However, with the implementation of SBA, students are required to provide modules and training to obtain the achievement band. If students are still unable to master the same course or do not complete their course work according to the standard set, then they need to repeat it to succeed. This situation will make the assessment process more difficult and take more time to make repeated assessments. As such, teachers' readiness in terms of knowledge, skills and patience is crucial in their efforts to assess each student's level and ability. Teachers as assessors of the coursework assigned should have sufficient knowledge and skills to successfully implement SBA in their respective schools.

Therefore, this study supports the opinion of Rohaya and Mohd Najib (2008) who stated that teachers should understand the goals and procedures of implementing assessment so that they are not questioned and considered to be unprofessional until they take the easy path of assessment without proper planning. Mohd Anuar and Khamsawati (2010) also agree with the results of this study by pointing out that teachers who are in-depth knowledge of the goals and objectives of SBA are able to carry out a thorough assessment. This is because assessment is a series of learning processes that include collecting, recording scores, interpreting data and parsing information about student learning to achieve a learning goal and purpose (Asri, 2009). Therefore, it is important for teachers to understand all elements of assessment such as the instrument used, the group and level of student assessment, feedback or response given to student achievement, the assessment team which is the subject teachers and the setting of scores for each assessment carried out so that the goals and objectives of the assessment are meet.

Sh. Siti Hauzimah (2019) found that efforts to increase integrity in the implementation of school-based assessments were also at a high level given the willingness to disclose integrity in the teaching profession. This clearly demonstrates the characteristics of teacher professionalism in implementing SBA as stated by Akhiar Pardi, et al (2012) where the traits include being firm and objective, honest, genuine and honest, dedicated and committed and always ready. The teachers in this study showed a positive attitude towards the implementation of SBA KHB. Teachers make a strong commitment to their teaching profession. The majority of teachers stated that they still needed courses in improving assessment and mastery in SBA. Teachers should therefore be given greater exposure through short courses or in-person training 
organized by a particular party. According to Byron (1990), every program of educational professionalism must be able to meet the needs of individuals or teachers, while Lokman and Kalsom (2011) emphasize that those needs must be relevant to developmental needs. This is because teachers will be more interested in participating in organized educational activities if they are truly in tune with their needs. High ability and confidence are the catalyst for effective teacher teaching especially for student learning (Ling, et al, 2019). This is because teachers who are committed to teaching are always motivated and sincerely want to improve their performance.

It can be concluded that the level of teacher readiness in implementing SBA is high especially in terms of assessment skills, knowledge and attitude towards implementing SBA KHB. Teacher readiness depends on teachers' knowledge of the concepts and methods of implementation of SBA. Teachers are seen to understand and have skills in performing assessments by designing and setting assessment objectives appropriate to the level of student skills. Careful planning in accordance with the guidelines set by the Malaysian Examination Board will ensure the validity and reliability of the assessment. This, in turn, makes assessments in public schools and in the classroom especially to improve student achievement and improve the assessment of teaching and learning activities to be more meaningful.

\section{Conclusion}

It can be concluded that based on the attitude, readiness and integrity of teachers in conducting School Based Assessments (SBA), teachers should:

a) Positive thinking in making changes. Teachers should always be positive about all innovations in the relevant curriculum.

b) Teachers need to be prepared from various aspects such as interest, attitudes, skills and knowledge in conducting SBA.

c) Preparing to enhance pedagogical knowledge Teachers need to know pedagogical knowledge as it will influence teaching approaches and methods as well as the provision of teaching resources. Teachers need to know how to engage students in the form of presentations, examples, explanations and more so that they can be easily understood. This can encourage students to think outside the box from the resources or teaching materials provided by the teacher. The implementation of the SBA system will help students improve the knowledge and skills of what teachers provide.

d) Teacher planning should be designed so that the teaching and learning system can be easily implemented without the hassle of not having enough time to provide relevant learning content. Teachers should be wise in managing their time so that the work is not swirling and may be ready at the appointed time. The provision of student information is important in the evaluation process so that the information the pupils make in the planning of the Teacher should be designed so that the teaching and learning system is accessible to those involved for a student.

e) Assessing their students at the same time teachers can assist, monitor and implement improvements. This means that you teach everything in SBA KSSR. Success or failure of a student depends on the value of a teacher's integrity.

f) The challenge for SBA will always be. The shortcomings and all the errors that are wrong should not be the reason and undermine the SBA start-up. Students, teachers, and society have 
the right to make the best contribution to the future of our nation, nation, and people and everything begins with the personal integrity of a human teacher.

\section{Summary}

Assessment is an important component of education because it provides information about student development to teachers, parents and students themselves. The assessment results can help teachers evaluate the teaching methods and activities implemented in the teaching and learning process. The Ministry is concerned about the allegation that the National education system is over exams. In order to ensure the smooth implementation of SBA, teachers should use the Curriculum Standard Documents containing the things to be learned and should be included in the teaching and learning process while the Performance Standard Document is the primary reference for assessing and measuring student achievement. Teachers are given the recognition and autonomy to conduct formative assessments during teaching and learning or at the end of the unit or at the end of the year. To assess teachers does not necessarily provide a workbook for each of the skills to be evaluated. Evidences of student mastery can be obtained through observations, oral answers, exercises in training books or workbooks and even homework. SBA does not limit the creativity of teachers who know their students better. Thus, it is clear how important it is for a teacher to have a positive attitude, willingness and integrity in implementing SBA.

\section{References}

Abd. Aziz Abd. Talib (2007). Pedagogi Bahasa Melayu: Prinsip, kaedah dan teknik. Edisi Keempat. Kuala Lumpur: Utusan Publication \& Distributors Sdn. Bhd

Abdul Said \& Shanti Gobalakrishnan (2017). Tahap Integriti dan Kesediaan Guru Dengan Pelaksanaan Pentaksiran Berasaskan Sekolah. International Journal of Education, Psychology and Counselling, 2 (4): 1-22.

Ahmad Mahdzan Ayob. (2005). Kaedah Penyelidikan Sosioekonomi. Edisi ketiga. Kuala Lumpur: Dewan Bahasa dan Pustaka.

Akhiar Pardi, Shamsina Shamsuddin dan Muhammad Kushairi Jusoh (2012) Asas kepimpinan \& perkembangan profesional guru. Kuala Lumpur: Freemind Horizons,

Ali, Z. (2008). Pelaksanaan pentaksiran kerja kursus kemahiran hidup bersepadu di Sekolah menengah luar bandar daerah Kuantan: Pahang. Universiti Teknologi Malaysia. Disertasi Sarjana

Amir Hassan Dawi (2006). Penteorian sosiologi dan pendidikan. Quantum Books, Tanjung Malim, Perak

Aniza Ahmad \& Zamri Mahamod (2015). Tahap kemahiran guru Bahasa Melayu sekolah menengah dalam melaksanakan pentaksiran berasaskan sekolah berdasarkan jantina, opsyen dan tempat mengajar. Jurnal Pendidikan Bahasa Melayu, 5 (1): 18-29.

Asri Selamat (2009). Amalan Pentaksiran Dalam Pengajaran Dan Pembelajaran Sekolah Menengah Bestari Di Negeri Johor. Universiti Teknologi Malaysia. Disertasi Sarjana

Atan Long (1984). Pendidik dan Pendidikan. Petaling Jaya: Penerbit Fajar Bakti Sdn.

Azlin Norhaini Mansor, Ong Hee Leng, Mohamad Sattar Rasul, Rose Amnah Raof \& Nurhayati Yusoff. (2013). The Benefits of School-Based Assessment. Universiti Kebangsaan Malaysia, Open University Malaysia, Universiti Malaya \& Multimedia University Malaysia.

Byron, M. (1990). Teacher Acceptance of a Peer Training Programme. Educational Research. 32. 66-71

Chew, F. P., \& Muhamad, N. (2017). Readiness of Implementation of School-Based Assessment Among the Malay Language Teachers in National Schools. Advanced Science Letters, 23(3), 2169-2173. 
Fraenkel, J. R., \& Wallen, N. E. (2006). How to design and evaluate research in education (6th ed.). New York, NY: McGraw-Hill.

Gay, L. R., \& Airasian (2003). Educational Research Competencies for Analysis and Applications (7th ed.). Upper Saddle River, NJ Merrill/Prentice Hall.

Ismadiah Omar (2011). Pelaksanaan Pentaksiran Berasaskan Sekolah (SBA) di Sekolahsekolah Kebangsaan Kawasan Gelang patah, Johor Bahru. Tesis Sarjana Muda Pendidikan. Universiti Teknologi Malaysia, Skudai.

Jumaniah Abd Mutalib, Zakiah Noordin \& Mohamad Nizam Nazarudin (2018). Hubungan Kerja Berpasukan Dan Pengupayaan Guru Dengan Komitmen Organisasi Di Sekolah Rendah. Jurnal Ilmiah. 11, 58-71.

Kalawathi, R. (2013). Faktor demografi yang mempengaruhi kesediaan guru matematik tahun 3 dalam pelaksanaan kurukulum standard sekolah rendah (KSSR) di Sekolah Jenis Kebangsaan Tamil, Perak. Thesis Sarjana, Universiti Sains Malaysia

Krejcie, R.V. \& Morgan, D.W. (1970) Determining Sample Size for Research Activities. Educational and Psychological Measurement, 30, 607-610.

Ling, L., Nazarudin, M. N., \& Noordin, Z. (2019). Kepuasan Kerja dan Efikasi Guru Tingkatan Enam di Pantai Barat Sabah. International Journal of Education, Psychology and Counseling, 4 (32), 51-66.

Lokman Mohd Tahir and Kalsom Saleh (2011) Implikasi latihan dalaman kepada guru-guru sekolah rendah. Journal of Science \& Mathematics Education. pp. 1-9.

Maslin Adnan. (2014). Amalan Pentaksiran Berasaskan Sekolah (PBS) dan Integriti Guru Matematik Sekolah Menengah. Fakulti Pendidikan. Johor Baru: Universiti Teknologi Malaysia.

Maxwell, G. (2006). Quality management of school-based assessments: Moderation of teacher judgments. Paper presented at the 32nd IAEA Conference, Singapore.

Mohamed Najib Abdul Ghaffar (1999) Penyelidikan Pendidikan. Universiti Teknologi Malaysia. Skudai

M. N. Ghafar, Pembinaan \& Analisis Ujian Bilik Darjah. Edisi Kedua. Skudai: Penerbit UTM Press, 2001.

Mohamed Najib Abdul Ghaffar (2001). Pembinaan \& Analisis Ujian Bilik Darjah. 2 ed. Skudai: Penerbit UTM Press.

Mohd Anuar Abdul Rahman dan Khamsawati Jaafar. (2010). Pelaksanaan Pentaksiran Kerja Kursus Kemahiran Hidup Bersepadu Sekolah Menengah Dalam Bandar Di Daerah Kuantan, Pahang. Universiti Teknologi Malaysia. Disertasi Sarjana

Mohd Isha Awang (2011). Pelaksanaan pentaksiran berasaskan sekolah: pengetahuan dan amalan guru di sekolah menengah agama milik kerajaan negeri. Prosiding Seminar Majlis Dekan-dekan Pendidikan IPTA 2011, 891-901.

Mohd Johdi Salleh (2008). Guru efektif dan peranan guru dalam mencapai objektif persekolahan sekolah rendah. Jurnal Pendidikan. 14(3):1-4.

Mohd Majid Konting. (2000). Kaedah Penyelidikan Pendidikan. Kuala Lumpur: Dewan Bahasa dan Pustaka

Mohd Noor, N. \& Sahip, S. (2010). Pelaksanaan pentaksiran kerja kursus berasaskan sekolah bagi matapelajaran kemahiran hidup di sekolah menengah kebangsaan daerah Johor Bahru, Kawasan Skudai (Universiti Teknologi Malaysia Institutional Repository). Johor, Malaysia: UTM.

Mohd Safarin Nordin \& Nur Hidayah Ismail (2014). Kesediaan Guru Terhadap Perlaksanaan Pentaksiran Berasaskan Sekolah Bagi Mata Pelajaran Kemahiran Hidup Bersepadu Sekolah Menengah Kebangsaan Mersing. International Seminar On Technical And Vocational Education 2014 (Tveis 2014) 
Nazarudin, M. N., Abdullah, N. F. L. B., \& Noordin, Z. (2017). Profesionalisme, Kesediaan Mengajar Guru Pelatih Dan Penyeliaan Pengajaran Pensyarah Pembimbing Praktikum Di Institut Pendidikan Guru Zon Sabah. International Journal of Education, Psychology and Counseling (IJEPC), 2(4), 71-84.

Noor Suadah Mohd Nawawi (2014) Integriti Guru Dalam Pelaksanaan Pentaksiran Berasaskan Sekolah (SBA) Di Sekolah Rendah Luar Bandar Kulaijaya. Disertasi Master. Universiti Teknologi Malaysia

Ramlah Ab Khalid, Jamil Ahmad \& Analisa Hamdan (2015). Pembentukan Sikap Positif Guru Terhadap Pelaksanaan Aktiviti Pentaksiran. Journal of Personalized Learning, 1(1), 77-84.

Rohaya Talib dan Mohd Najib Abdul Ghafar. (2008). Pembinaan Instrumen Bagi Mengukur Tahap Literasi Pentaksiran Guru Sekolah Menengah di Malaysia. Seminar Penyelidikan Pendidikan Pasca Ijazah. Pusat Latihan UTM, Skudai, 25-27 November 2008.

Sanitah Mohd Yusof \& Norsiwati Ibrahim. (2012). Kesediaan guru Matematik tahun satu dalam pelaksanaan Kurikulum Standard Sekolah Rendah (KSSR) di Daerah Kluang. Journal of Science and Mathematics Education, 6, 26-38

Shafinaz A. Maulod. (2017). Hubungan antara Kecerdasan Emosi dan Kepimpinan Instruksional Pengetua dengan Efikasi Kendiri Guru Sekolah Menengah Kebangsaan di Negeri Sembilan. Kuala Lumpur: Universiti Malaya.

Sh. Siti Hauzimah Wan Omar (2019). Pengetahuan, Kemahiran, Sikap Dan Masalah Guru Dalam Melaksanakan Pentaksiran Bilik Darjah Bahasa Melayu Di Sekolah Rendah. Jurnal Pendidikan Bahasa Melayu, 9(1) : 56-67 56

Stiggins, R. J., \& Bridgeford, N. J. (1985). The ecology of classroom assessment. Journal of Educational Measurement, 22(4), 271-286.

Tuan Azlyna Tuan Soh. (2013). Kesediaan guru dalam melaksanakan pentaksiran bilik darjah Bahasa Melayu di sekolah menengah. Kertas Projek Sarjana Pendidikan. Fakulti Pendidikan, Universiti Kebangsaan Malaysia.

Tyler, R. W. (1949). Basic principles of curriculum and instruction. Chicago: University of Chicago Press.

Wiseman, D. C. (1999). Research Strategies for Education. Belmont, CA: Wadsworth Publishing Company

Zalinah Mohamed (2014). Integriti Guru Dalam Pelaksanaan Pentaksiran Berasaskan Sekolah Kurikulum Standard Sekolah Rendah Di Empat Buah Sekolah Rendah Di Daerah Tampoi, Johor Bahru. Master Projek Paper. Universiti Teknologi Malaysia. 